\title{
Presence of Chlorinated Paraffins in Sediments from the North and Baltic Seas
}

\author{
Jan Hüttig, Michael Oehme \\ Organic Analytical Chemistry, University of Basel, Neuhausstr. 31, CH-4057, Basel, Switzerland
}

Received: 28 January 2005/Accepted: 30 April 2005

\begin{abstract}
Chloroparaffins (CPs) were determined in sediments collected from the North and Baltic Seas during monitoring campaigns in 2001-2003. Electron ionization tandem mass spectrometry (MS/MS) was used for a first screening. It allowed the simultaneous determination of short (SCCP) and medium chain chlorinated paraffins (MCCP). SCCP+MCCP concentrations between 5 and $499 \mathrm{ng} / \mathrm{g}$ dry weight were found. In general, Baltic Sea sediments were more highly contaminated by CPs than the North Sea was. However, concentrations related to the total organic carbon content were on the same order of magnitude due to the higher organic content in the Baltic Sea. Additional information about the congener and homologue pattern was obtained for selected samples from the Baltic Sea by high-resolution gas chromatography combined with negative ion chemical ionization and low-resolution mass spectrometry, Concentrations in the North Sea were in general too low for this approach. In the Baltic Sea, MCCP concentrations were 1.7-2.4 times higher than for SCCPs. Lower chlorinated $\mathrm{C}_{13}$ and $\mathrm{C}_{14}$ compounds were the main $\mathrm{CP}$ compounds. The $\mathrm{CP}$ congener and homologue patterns showed similarities with technical SCCP and MCCP mixtures when compared using principal component analysis.
\end{abstract}

The determination of environmental levels of chlorinated paraffins (CPs) is a challenge due to the high complexity of the applied technical mixtures. Formulations contain varying carbon chain lengths between $\mathrm{C}_{10}$ and $\mathrm{C}_{30}$ and chlorination degrees between $30 \%$ and $70 \%$ and consist of several thousands of isomers and homologues (Zitko 1973). This makes their analysis extremely complex.

Recent reviews report the presence of CPs in the aquatic and terrestrial environment and in sewage sludge (European Chemicals Bureau 2002; European Commission 1999; Tomy et al. 1998, 2000; World Health Organization 1996). Data from Europe are compiled in two risk assessment reports for short chain (SCCP) and medium chain (MCCP) polychlori-

Correspondence to: Michael Oehme; email: Michael.Oehme@ unibas.ch nated $n$-alkanes (European Chemicals Bureau 2002; European Commission 1999). Their wide range use in rubber, adhesives, lubricants, and as flame-retardant plasticizers has led to their dispersion into the environment, where they can be found in water, biota, food, as well as in remote areas (Nicholls et al. 2001). Studies have demonstrated that SCCPs are toxic to aquatic organisms and bioaccumulate in different species (Tomy et al. 1998). Furthermore, the short chain CPs are carcinogenic in mice and rats. The International Agency for Research on Cancer (IARC) has classified SCCPs in group 2B as possibly carcinogenic to humans (World Health Organization 1996). Consequently, several organizations and environmental agencies have imposed regulations on the application and/or environmental release of SCCPs. In particular, water pollution by SCCPs is of concern. Therefore, the European Union included SCCPs in the list of priority hazardous substances in the water policy directive 2000/60/ EC (European Community 2000, 2001). It contains substances that are persistent, toxic, and bioaccumulate in food webs. Moreover, this measure requires the development of appropriate analytical methods for the investigation of environmental concentrations.

In the past 2 decades, SCCP concentrations have been determined occasionally in air, water, sediment, sewage sludge, and biota (Marvin et al. 2003; Muir et al. 2000; Stevens et al. 2003). In Canada, SCCP concentrations were between 7 and $290 \mathrm{ng} / \mathrm{g}$ in surface sediments from harbor areas along Lake Ontario. The highest concentrations were found in the most industrialized areas. Tomy et al. (1999) reported a significant decline of SCCP concentrations in surface sediments from $135 \mathrm{ng} / \mathrm{g}$ dry weight in the southern basin of Lake Winnipeg to $5 \mathrm{ng} / \mathrm{g}$ in Lake Hazen on Ellesmere Island (high Arctic). In sediments collected from the mouth of the Detroit River at Lake Erie, the SCCP concentration was $1800 \mathrm{ng} / \mathrm{g}$ (Stern et al. 2000). SCCP levels in German river sediments (Rhine, Main, Outer Alster, Elbe, Lech, and Danube) ranged between $<5$ and $83 \mathrm{ng} / \mathrm{g}$ dry weight in 1994. The concentrations in sediment from Lake Constance varied between 6 and 10 ng/g (World Health Organization 1996). SCCP concentrations between 24 and $46 \mathrm{ng} / \mathrm{g}$ dry weight were determined in freshwater sediments for a background area in the Czech Republic and between 5 and $181 \mathrm{ng} / \mathrm{g}$ for two areas influenced by industry (Stejnarova et al. 2005). Levels of SCCPs in river sediments were in the range of $250 \mathrm{ng} / \mathrm{g}$ to $3260 \mathrm{ng} / \mathrm{g}$ in Spain (Parera et al. 2004). 
A literature survey showed that even less is known about environmental levels of medium chain CPs compared to SCCPs. Because of stringent regulations on the use of SCCPs by environmental agencies, the worldwide use of MCCPs might increase. In Europe, the consumption of MCCPs has already exceeded that of SCCPs (70\% MCCP and 15\% SCCP in 1994) (World Health Organization 1996). The use of SCCP within the EU has been reduced from 13,000 tonnes to 4000 tonnes over the period 1994-1998 and the total production was $\leq 15,000$ tonnes in 1994 (HELCOM 2002). The current total MCCP production capacity is in the range 45,000160,000 tonnes/year in the European Union (European Chemicals Bureau 2002). A MCCP concentration of $68 \mathrm{ng} / \mathrm{g}$ sediment was reported from the mouth of the Detroit River in Lake Erie (Stern et al. 2000). In sediment from Hamilton Harbor (Windemere Basin), a MCCP level of $290 \mathrm{ng} / \mathrm{g}$ dry weight was measured (Muir et al. 2000). MCCP concentrations of $<10-370 \mathrm{ng} / \mathrm{g}$ were determined in German river sediments in 1994 and $5 \mathrm{ng} / \mathrm{g}\left(\mathrm{C}_{14-18}\right)$ in surface sediment from Lake Zürich (World Health Organization 1996). Kemmlein et al. showed MCCP concentrations between 1108 and 16,403 ng/g d.w. in marine sediments from Australia and the presence of long chain chlorinated paraffins (Kemmlein et al. 2002).

The objectives of this work were to study the CP distribution in North Sea and Baltic Sea sediments, since data are completely missing. A recently developed technique based on electron ionization (EI) tandem mass spectrometry (MS/MS) was used for a first screening of CP levels in sediments, It allowed the simultaneous determination of SCCPs and MCCPs (SCCP+MCCP concentration). Then, additional information about the congener and homologue patterns of selected samples was obtained by high-resolution gas chromatography (HRGC) combined with negative ion chemical ionization (NICI) low-resolution mass spectrometry (LRMS) using methane/dichloromethane as reagent gas. Results are discussed and compared with relevant data.

\section{Materials and Methods}

\section{Chemicals}

$\operatorname{SCCP}\left(\mathrm{C}_{10-13}, 55.5 \% \mathrm{Cl}\right.$ content $)$ and $\mathrm{MCCP}\left(\mathrm{C}_{14-17}, 57.0 \% \mathrm{Cl}\right.$ content) technical mixtures were purchased from Ehrenstorfer (Augsburg, Germany) as solutions in cyclohexane (concentration $100 \mathrm{ng} / \mu \mathrm{l}$ ), ${ }^{13} \mathrm{C}_{10}$-trans-chlordane (Cambridge Isotope Laboratories, Mandover, Massachusetts) and octachloronaphthaline (OCN, Ehrenstorfer, Germany) were used as internal standards $(1 \mathrm{ng} / \mu \mathrm{l})$, and hexachlorocyclohexane $(\mathrm{HCH}$, Ehrenstorfer, Germany) was employed as recovery standard at a concentration of $1 \mathrm{ng} / \mu \mathrm{l}$ in cyclohexane, SCCP mixtures such as $55.5 \% \mathrm{Cl}$ from Dr. Ehrenstorfer, Germany, Hordalub 17, 80, and 500 from Hoechst, Germany as well as MCCP mixtures, $57.0 \% \mathrm{Cl}$ from Dr, Ehrenstorfer, Germany, Hordaflex SP, Hordalub 80 EM, Chlorparaffin 40fl and 45fl from Hoechst, Germany, and Cloparin 50 from Caffaro, Italy were solved in cyclohexane in concentrations of $7.5 \mathrm{ng} / \mu \mathrm{l}$.

All solvents were of pesticide residue grade and obtained from Scharlau (Barcelona, Spain). Florisil ${ }^{\circledR}(60-100$ mesh) and sodium sulfate (Pestanal) were purchased from Fluka (Uetikon, Switzerland), and silica gel from Merck (0.04-0.063 mm, Darmstadt, Germany).
Table 1. Location, sampling date, and TOC content of sediment samples selected for $\mathrm{CP}$ analysis

\begin{tabular}{llll}
\hline Sample & \multicolumn{1}{c}{ Location } & TOC $(\%)$ & \multicolumn{1}{c}{ Year } \\
\hline \multicolumn{2}{c}{ North Sea/German Bight } & & \\
1 & $53^{\circ} 40.40^{\prime} \mathrm{N} / 6^{\circ} 30.00^{\prime} \mathrm{E}$ & 0.06 & May 2003 \\
2 & $54^{\circ} 02.00^{\prime} \mathrm{N} / 8^{\circ} 12.50^{\prime} \mathrm{E}$ & 0.34 & September 2002 \\
3 & $54^{\circ} 04.00^{\prime} \mathrm{N} / 8^{\circ} 07.50^{\prime} \mathrm{E}$ & 1.67 & September 2002 \\
4 & $54^{\circ} 14.00^{\prime} \mathrm{N} / 8^{\circ} 22.50^{\prime} \mathrm{E}$ & 0.57 & September 2002 \\
5 & $54^{\circ} 22.50^{\prime} \mathrm{N} / 7^{\circ} 38.70^{\prime} \mathrm{E}$ & 0.07 & May 2003 \\
6 & $54^{\circ} 30.00^{\prime} \mathrm{N} / 6^{\circ} 30.00^{\prime} \mathrm{E}$ & 0.23 & May 2003 \\
7 & $54^{\circ} 30.00^{\prime} \mathrm{N} / 7^{\circ} 48.00^{\prime} \mathrm{E}$ & 0.21 & September 2002 \\
8 & $54^{\circ} 30.00^{\prime} \mathrm{N} / 7^{\circ} 60.00^{\prime} \mathrm{E}$ & $<\mathrm{LOD}$ & September 2002 \\
9 & $54^{\circ} 45.00^{\prime} \mathrm{N} / 8^{\circ} 12.00^{\prime} \mathrm{E}$ & 0.10 & September 2002 \\
10 & $55^{\circ} 00.00^{\prime} \mathrm{N} / 6^{\circ} 30.00^{\prime} \mathrm{E}$ & 0.37 & May 2003 \\
11 & $55^{\circ} 03.00^{\prime} \mathrm{N} / 8^{\circ} 12.00^{\prime} \mathrm{E}$ & 0.13 & May 2003 \\
12 & $55^{\circ} 04.00^{\prime} \mathrm{N} / 6^{\circ} 20.00^{\prime} \mathrm{E}$ & 0.46 & May 2003 \\
13 & $55^{\circ} 15.00^{\prime} \mathrm{N} / 4^{\circ} 30.00^{\prime} \mathrm{E}$ & 0.12 & May 2003 \\
14 & $55^{\circ} 45.00^{\prime} \mathrm{N} / 4^{\circ} 00.00^{\prime} \mathrm{E}$ & 0.07 & May 2003 \\
Baltic Sea & & & \\
15 & $54^{\circ} 02.90^{\prime} \mathrm{N} / 10^{\circ} 50.00^{\prime} \mathrm{E}$ & 2.90 & August 2001 \\
16 & $54^{\circ} 18.90^{\prime} \mathrm{N} / 11^{\circ} 33.10^{\prime} \mathrm{E}$ & 3.80 & August 2001 \\
17 & $54^{\circ} 25.10^{\prime} \mathrm{N} / 10^{\circ} 13.30^{\prime} \mathrm{E}$ & 3.10 & August 2001 \\
18 & & 5.28 & August 2002 \\
19 & $55^{\circ} 00.00^{\prime} \mathrm{N} / 14^{\circ} 05.00^{\prime} \mathrm{E}$ & 6.00 & August 2001 \\
20 & & 5.18 & August 2002 \\
\hline
\end{tabular}

LOD: limit of detection $(0.1 \%)$.

\section{Sediment Sampling}

Sediment samples were collected in the North and Baltic Seas (for sites see Table 1) by the Federal Maritime and Hydrographic Agency (Hamburg, Germany) in August/September 2001/2002 and May 2003. The samples were taken with a grab sampler (surface slice, $0-2 \mathrm{~cm}$ ) and frozen directly after sampling until analysis. Total organic carbon (TOC) was determined with a standard method by the Federal Maritime and Hydrographic Agency (Vario EL from Elementar, Germany), and data are listed in Table 1.

\section{Sample Pretreatment}

Sediments were dried at room temperature for 10 days (open-air dried in the lab) and sieved with 2-mm mesh size. Depending on the TOC content, $2-50 \mathrm{~g}$ sediments were selected and $10 \mu \mathrm{l}$ of a solution with ${ }^{13} \mathrm{C}_{10}$-trans-chlordane and $\mathrm{OCN}$ in cyclohexane (concentration of 1 $\mathrm{ng} / \mu \mathrm{l})$ added as internal standards. Soxhlet extraction was carried out with $200 \mathrm{ml}$ of $n$-hexane/ $\mathrm{CH}_{2} \mathrm{Cl}_{2}(1: 1, \mathrm{v} / \mathrm{v})$ overnight (glass fiber thimbles 603G, Schleicher \& Schuell, Dassel, Germany), elemental sulfur was removed with activated copper powder (230 mesh, Merck, Germany; activated with concentrated nitric acid) during the Soxhlet extraction. The extract was concentrated to $1 \mathrm{ml}$ using a Turbovap evaporation system (Zymark, Hutchinson, USA). It was purified with a column containing $1 \mathrm{~g}$ of water-free sodium sulfate, $16 \mathrm{~g}$ of Florisil ${ }^{\circledR}$ $(1.5 \%$ water $(\mathrm{w} / \mathrm{w})$ ), and $1 \mathrm{~g}$ of sodium sulfate (glass column $20 \mathrm{~cm}$ long, $1.5 \mathrm{~cm}$ i.d.). Conditioning of the column was carried out with 40 $\mathrm{ml}$ of $n$-hexane. Fraction 1 was eluted with $60 \mathrm{ml}$ of $n$-hexane and 5 $\mathrm{ml}$ of $\mathrm{CH}_{2} \mathrm{Cl}_{2}$ and fraction 2 with $55 \mathrm{ml}$ of $\mathrm{CH}_{2} \mathrm{Cl}_{2}$. The latter contained the CPs. Ten nanograms of $\epsilon-\mathrm{HCH}$ in $10 \mu \mathrm{l}$ cyclohexane were added as recovery standard, and the extract was concentrated to $200 \mu \mathrm{l}$ by a Turbovap evaporation system before analysis. Quantification was carried out using a technical SCCP mixture with $55.5 \%$ and a MCCP mixture with $57.0 \%$ chlorine content as reference. 
For sediments with higher TOC content, an additional clean-up step was necessary. Sample matrix not persistent to sulfuric acid was removed prior to the Florisil ${ }^{\circledR}$ clean-up by a column containing $1 \mathrm{~g}$ of water-free sodium sulfate, $20 \mathrm{~g}$ of silica gel/sulfuric acid (44\%), and 1 $\mathrm{g}$ of sodium sulfate (glass column $20 \mathrm{~cm}$ long, $2.0 \mathrm{~cm}$ i.d.). The extract was concentrated to $1 \mathrm{ml}$ was placed on top of the column, and the CP fraction was eluted with $70 \mathrm{ml} n$-hexane/ $\mathrm{CH}_{2} \mathrm{Cl}_{2}(1+1, \mathrm{v} / \mathrm{v})$.

\section{Quality Assurance}

These following measures were taken to avoid contamination and $\mathrm{CP}$ background. Sodium sulfate, Florisil ${ }^{\circledR}$ and silica gel were heated to $600^{\circ} \mathrm{C}$ for $24 \mathrm{~h}$. Glassware was soaked in a water bath overnight $(20 \%$ Deconex per 1, VWR, Switzerland), rinsed with water, and heated to $450^{\circ} \mathrm{C}$ overnight in a furnace (FE $110 \mathrm{H} \mathrm{SEV}$ from Rohde, Prutting, Germany). Glass fiber thimbles were heated to $500^{\circ} \mathrm{C}$ prior to use. New batches of solvents were analyzed for SCCPs and MCCPs. In general, levels of CPs were below the limit of detection (see Results and Discussion) in solvents and in the method blank (calcinated seas and heated to $600^{\circ} \mathrm{C}$ ).

\section{$E I-M S / M S$}

Gas chromatographic separations were performed on a CP-3800 (Varian, Walnut Creek, CA) gas chromatograph equipped with a split/ splitless injector and a fused silica capillary column $(15 \mathrm{~m}, 0.25 \mathrm{~mm}$ i.d.) coated with a $0.25 \mu \mathrm{m}$ film of $5 \%$ crosslinked phenylmethylpolysiloxane (DBS-MS, J\&W Scientific, Folsom, CA). Splitless injections (1.5 $\mathrm{min})$ of $2.5 \mu \mathrm{l}$ volume were carried out at an injector temperature of $275^{\circ} \mathrm{C}$ (Combi Pal autosampler, CTC Analytics, Zwingen, Switzerland). Helium was used as carrier gas at a constant flow of $2 \mathrm{ml} / \mathrm{min}$. The temperature program for EI-MS/MS was as follows: $100^{\circ} \mathrm{C}$, isothermal for $1 \mathrm{~min}$, then $50^{\circ} \mathrm{C} / \mathrm{min}$ to $300^{\circ} \mathrm{C}$, isothermal for $4 \mathrm{~min}$.

A triple quadrupole mass spectrometer $1200 \mathrm{~L}$, (Varian) was employed (Zencak et al. 2004). Parameters were, in brief: Transfer line temperature $270^{\circ} \mathrm{C}$, ion source temperature $200^{\circ} \mathrm{C}$, manifold temperature $40^{\circ} \mathrm{C}, \mathrm{EI}-\mathrm{MS} / \mathrm{MS}$ spectra were recorded at $70 \mathrm{eV}$ (emission current $300 \mu \mathrm{A}$, dwell time $40 \mathrm{~ms}$, resolution of Q1 at $0.8 \mathrm{u}$ and of Q3 at $1.2 \mathrm{u}$ and $\arg$ on at $0.12-0.15 \mathrm{~Pa}$ ). $\mathrm{CP}$ quantification was carried out with the collision-induced dissociation (CID) $\mathrm{m} / \mathrm{z} 91 \rightarrow 53, \mathrm{~m} / \mathrm{z}$ $102 \rightarrow 65$, and $m / z 102 \rightarrow 67$ (collision energy $-10.0 \mathrm{~V},-10.0 \mathrm{~V}$, and $-18.0 \mathrm{~V})$. The precursor ion $\mathrm{m} / z 383[\mathrm{M}-\mathrm{Cl}]^{+}$and the product ion $\mathrm{m} / z, 276[\mathrm{M}-4 \mathrm{Cl}]^{+}$were chosen for ${ }^{13} \mathrm{C}_{10}$-trans-chlordane (collision energy $-21.0 \mathrm{~V})$

\section{$\mathrm{CH}_{4} / \mathrm{CH}_{2} \mathrm{Cl}_{2}-\mathrm{NICI}-\mathrm{MS}$}

Gas chromatographic separations were performed on a HP5890II (Hewlett Packard, Palo Alto, CA) gas chromatograph equipped with a split/splitless injector and a fused silica capillary column $(15 \mathrm{~m}, 0.25$ mm i.d.) coated with a film of $0.25 \mu \mathrm{m}$ of $5 \%$ crosslinked phenylmethylpolysiloxane (DB5-MS, J\&W Scientific, Folsom, CA). Splitless injections (splitless time $2 \mathrm{~min}$ ) of $2 \mu \mathrm{l}$ volume were carried out at an injector temperature of $275^{\circ} \mathrm{C}$. Helium (99.999\%, Carbagas, Basel, Switzerland) was used as carrier gas at a column inlet pressure of 68.9 $\mathrm{kPa}$ (10 psi). The temperature program was as follows: $100^{\circ} \mathrm{C}$, isothermal for $2 \mathrm{~min}$, then $10^{\circ} \mathrm{C} / \mathrm{min}$ to $260^{\circ} \mathrm{C}$, isothermal for $10 \mathrm{~min}$.

A quadrupole mass spectrometer (HP5889B, Hewlett Packard, Palo Alto, CA) was employed in the electron capture negative ion mode (ECNI) with methane as reagent gas $(99.995 \%$, Carbagas, Basel,
Switzerland). The ion source temperature was $200^{\circ} \mathrm{C}$, the quadrupole temperature was $100^{\circ} \mathrm{C}$, and the transfer line temperature was $280^{\circ} \mathrm{C}$. The electron energy was $100 \mathrm{eV}$. The mass spectrometer was tuned to optimal performance using perfluorotributylamine at $\mathrm{m} / \mathrm{z}, 283,414$, and 452. $\mathrm{CH}_{2} \mathrm{Cl}_{2}$ (Scharlau, Barcelona, Spain) was introduced through a modified transfer line by adding a T-piece and a small glass bulb of $6 \mathrm{ml}$ volume filled with dichloromethane (Zencak et al. 2003b). A needle valve was used to meter the dichloromethane pressure, $\mathrm{CH}_{4} /$ $\mathrm{CH}_{2} \mathrm{Cl}_{2}$-NICI was performed at a total reagent gas pressure of 2.0 mbar (1.5 Torr) measured at the transfer line inlet and a $\mathrm{CH}_{4} / \mathrm{CH}_{2} \mathrm{Cl}_{2}$ ratio of 4:1. CPs were detected in the selected ion monitoring (SIM) mode using the most abundant isotope ion $[\mathrm{M}+\mathrm{C} 1]^{-}$of each $\mathrm{CP}$ compound (dwell time $75 \mathrm{~ms}$ per ion) and $\mathrm{m} / \mathrm{z}, 419.8$ for the internal standard ${ }^{13} \mathrm{C}_{10}$-trans-chlordane. Further details are described elsewhere (Zencak et al. 2003b).

\section{Quantification}

Under $\mathrm{CH}_{4} / \mathrm{CH}_{2} \mathrm{Cl}_{2}$-NICI conditions, CPs form almost exclusive $[\mathrm{M}+\mathrm{Cl}]^{+}$adduct ions (Zencak et al. 2003a). The most abundant $[\mathrm{M}+\mathrm{Cl}]^{-}$ion for each congener group $\left(\mathrm{C}_{10-15} \mathrm{Cl}_{4-10}\right)$ was used for quantification according to Tomy et al. (1997), and the applied quantification procedure was similar to a previously described method (Hüttig and Oehme 2005).

\section{Principal Component Analysis (PCA)}

Congener and homologue patterns of seven different sampled locations and of different technical SCCP (see Chemicals) were used for principal component analysis, The software program Statistica 5.5 (StatSoft, USA) was used for multivariate data analysis.

Each congener pattern was expressed as an object vector described by $\mathrm{N}$ variables in one matrix. The $\mathrm{N}$ variables were the relative abundance of each $\mathrm{CP}$ congener $\left(\mathrm{C}_{10-15}\right.$ with 4-10 chlorine atoms, $\mathrm{N}=28$ for SCCP and $\mathrm{N}=14$ for MCCP). PCA allows reduction of the multidimensionality of a data set, while retaining as much information as possible. For this purpose, new descriptors are generated called latent variables or principal components (PC). Their content of information is expressed by their variance, the higher the more information they represent. The result of a PCA can be presented as score plot, where the distance between object vectors (congener profiles of sample locations) describes the relationship between objects.

\section{Results and Discussion}

High-resolution MS (HRMS) is often used for CP analysis to avoid interferences from other chlorinated compounds with the same mass-to-charge ratio and retention time range (Tomy et al. 1997). However, recent publications showed that LRMS can be used (Castells et al. 2004; Zencak et al. 2005). This requires an efficient sample clean-up (Parera et al. 2004; Reth et al. 2005) and a special approach to eliminate interferences by mass overlap (Reth and Oehme 2004).

\section{Clean-up}

CPs elute in a retention time range overlapping with those of other chlorinated compounds such as toxaphenes, PCBs, and chlordanes. The applied Florisil column was efficient for the 
removal of toxaphenes, DDT compounds, $\mathrm{PCB}$, and heptachlor as the test with model compounds demonstrated. These substances eluted completely in the first fraction. $\alpha-\mathrm{HCH}$, cis/ trans-chlordane, and cis-nonachlor coelute with CPs in the second fraction of the Florisil column trans-Nonachlor was found in both fractions. Stejnarova et al. (2005) also emphasized the need for the complete elimination of interfering substances, especially toxaphene and PCBs.

\section{Method Validation}

Recoveries of SCCPs and MCCPs were about $80 \%$ for spiked sediment samples $(0.5-1.5 \mu \mathrm{g}$ of technical $\mathrm{CP}$ mixture) determined by HRGC-ECNI-LRMS (Zencak et al. 2005). The recovery of the internal standard OCN was between $80 \%$ and $90 \%$ and of ${ }^{13} \mathrm{C}_{10}$-trans-chlordane between $70 \%$ and $80 \%$.

Limits of detection at a signal-to-noise ratio of 3:1 (HRGCNICI-LRMS) were for technical mixtures $1 \mathrm{ng} / \mu \mathrm{l}$ for SCCP $(55.5 \% \mathrm{Cl})$ and $0.5 \mathrm{ng} / \mu \mathrm{l}$ for MCCP $(57.0 \% \mathrm{Cl})$. Limits of quantification at a signal-to-noise ratio of $10: 1$ were $1-2 \mathrm{ng} / \mu \mathrm{l}$ for SCCP/MCCP depending on the selected CP component. The linearity of a six-point calibration between 2 and $100 \mathrm{ng} /$ $\mu l$ was good for SCCP $\left(\mathrm{R}^{2}>0.998\right)$ and MCCP (8 points, range $1-100 \mathrm{ng} / \mu \mathrm{l}\left(\mathrm{R}^{2}>0.994\right)$.

Linearity for EI-MS/MS was adequate for a concentration range of $0.5-100 \mathrm{ng} / \mu \mathrm{l}$ of technical SCCP mixture for all CIDs $\left(\mathrm{R}^{2}>0.99\right.$, 7-9 measuring points). Detection and quantification limits (LOD and LOQ) for a SCCP technical mixture with $55.5 \%$ chlorine content were in the range of $0.1-0.54 \mathrm{ng} / \mu \mathrm{l}$ and 0.4-1.2 $\mathrm{ng} / \mu \mathrm{l}$ respectively, depending on the selected fragmentation. LODs and LOQs for a MCCP technical mixture with $57.0 \%$ chlorine content were in the range of $0.1-0.5 \mathrm{ng} / \mu \mathrm{l}$ and $0.4-1.6 \mathrm{ng} / \mu \mathrm{l}$. A recent method comparison showed that both methodologies give comparable results (Zencak et al. 2005).

\section{Screening of Sediment Samples with EI-MS/MS}

Total CP concentrations in sediments determined by EI-MS/ MS (Table 2, average of CIDs) were between 5 and $499 \mathrm{ng} / \mathrm{g}$ dry weight (d.w.). Levels of $\mathrm{C}_{10}-\mathrm{C}_{20}$ chloroparaffin in North Sea sediments published as early as 1980 were $<0.5-50 \mathrm{ng} / \mathrm{g}$ for three sediment locations (Campbell and McConnell 1980; Greenpeace 1995).

The differences were small between the quantification based on a SCCP or MCCP technical mixture with similar chlorine content $(<15 \%$ deviation). Except for sample 3, total CP concentrations in the North Sea (German Bight) were lower than in the Baltic Sea. In general, the concentrations in the North Sea were too low for a determination of the congener and homologue patterns by NICI-MS. However, total CP concentrations related to the TOC content were on the same order of magnitude for North Sea and Baltic Sea due to the high organic content of the Baltic Sea sediments (Table 1). The highest TOC based SCCP+MCCP concentration in the North Sea was found for sample 14 with $0.07 \%$ TOC. The highest total CP concentration was in sample 3 (Figure 1). This location showed also high concentrations of hexachlo-
Table 2. SCCP + MCCP concentrations in sediments from the North and Baltic Seas obtained with EI-MS/MS and given on dry weight basis $(\mathrm{ng} / \mathrm{g})$ and on total organic carbon content ( $\mu \mathrm{g} / \mathrm{g}$ TOC)

\begin{tabular}{lrrrrr}
\hline & \multicolumn{2}{c}{$\mathrm{CP}(\mathrm{ng} / \mathrm{g})$} & & \multicolumn{2}{c}{$\mathrm{CP}(\mu \mathrm{g} / \mathrm{g}$ TOC $)$} \\
\cline { 2 - 3 } \cline { 5 - 6 } Sample & $\mathrm{SCCP}^{\mathrm{a}}$ & $\mathrm{MCCP}^{\mathrm{b}}$ & & $\mathrm{SCCP}^{\mathrm{a}}$ & $\mathrm{MCCP}^{\mathrm{b}}$ \\
\hline 1 & 20 & 24 & 33 & 39 \\
2 & 14 & 13 & & 4.2 & 3.9 \\
3 & 112 & 146 & & 6.7 & 8.7 \\
4 & 27 & 28 & & 4.8 & 4.9 \\
5 & 15 & 18 & 21 & 25 \\
6 & 27 & 32 & 12 & 14 \\
7 & 8 & 9 & 3.7 & 4.3 \\
8 & 5 & 5 & & $\mathrm{c}$ \\
9 & 9 & 9 & 9.1 & 8.6 \\
10 & 25 & 30 & & 6.9 & 8.2 \\
11 & 16 & 19 & & 12 & 15 \\
12 & 16 & 18 & 3.4 & 4.6 \\
13 & 24 & 27 & 20 & 23 \\
14 & 33 & 40 & 47 & 57 \\
15 & 116 & 93 & 4.0 & 3.2 \\
16 & 141 & 115 & 3.7 & 3.0 \\
17 & 262 & 211 & 8.4 & 6.8 \\
18 & 377 & 499 & 7.1 & 9.6 \\
19 & 142 & 114 & 2.4 & 1.9 \\
20 & 108 & 122 & 2.1 & 2.3 \\
\hline
\end{tabular}

${ }^{\mathrm{a}}$ Quantification with SCCP and ${ }^{\mathrm{b}}$ MCCP standard. ${ }^{\mathrm{c}}$ No TOC available, see Table 1.

robenzene, polychlorinated biphenyls, DDT and hexachlorocyclohexanes in 1997 and 1998 (BLMP 2002). It is situated in the Elbe estuary. In 1994 SCCP and MCCP concentrations of 16-25 and 130-230 ng/g were determined in Elbe sediments at two sites in Hamburg (GDCh Advisory Committee on Existing Chemicals of Environmental Relevance 1992).

Sediment samples from the Baltic Sea had CP concentrations between 108 and 499 ng/g d.w. (Table 2). The highest total CP concentration in the Baltic Sea was found in sample 18 (Kieler Förde). CP concentrations of locations 17-20 were on same order of magnitude for two consecutive sampling years. Concentrations based on TOC were on the same order of magnitude compared to the North Sea due to the higher organic content in Baltic Sea sediments.

\section{Characterization of Sediment Samples by $\mathrm{CH}_{4} / \mathrm{CH}_{2} \mathrm{Cl}_{2}-\mathrm{NICI}$}

In contrast to $\mathrm{CH}_{4}$-ECNI (Muir et al. 2000), which is normally used for the determination of $\mathrm{CPs}, \mathrm{CH}_{4} / \mathrm{CH}_{2} \mathrm{Cl}_{2}$-NICI allowed the detection of lower chlorinated $\mathrm{CP}$ compounds. Moreover, the exclusive formation of $[\mathrm{M}+\mathrm{Cl}]^{-}$adduct ions and the better uniformity of the response factors reduced quantification problems and permitted a better characterization of technical CP mixtures (Zencak et al. 2003a). The application of $\mathrm{CH}_{4} /$ $\mathrm{CH}_{2} \mathrm{Cl}_{2}$ as reagent gas also resulted in an increased selectivity due to the reduced ionization of interfering organochlorines such as toxaphene and chlordanes.

Sediments with $>50 \mathrm{ng} / \mathrm{g} \mathrm{SCCP}+\mathrm{MCCP}$ concentrations (Table 2) were reanalyzed with $\mathrm{CH}_{4} / \mathrm{CH}_{2} \mathrm{Cl}_{2}$-NICI, which 


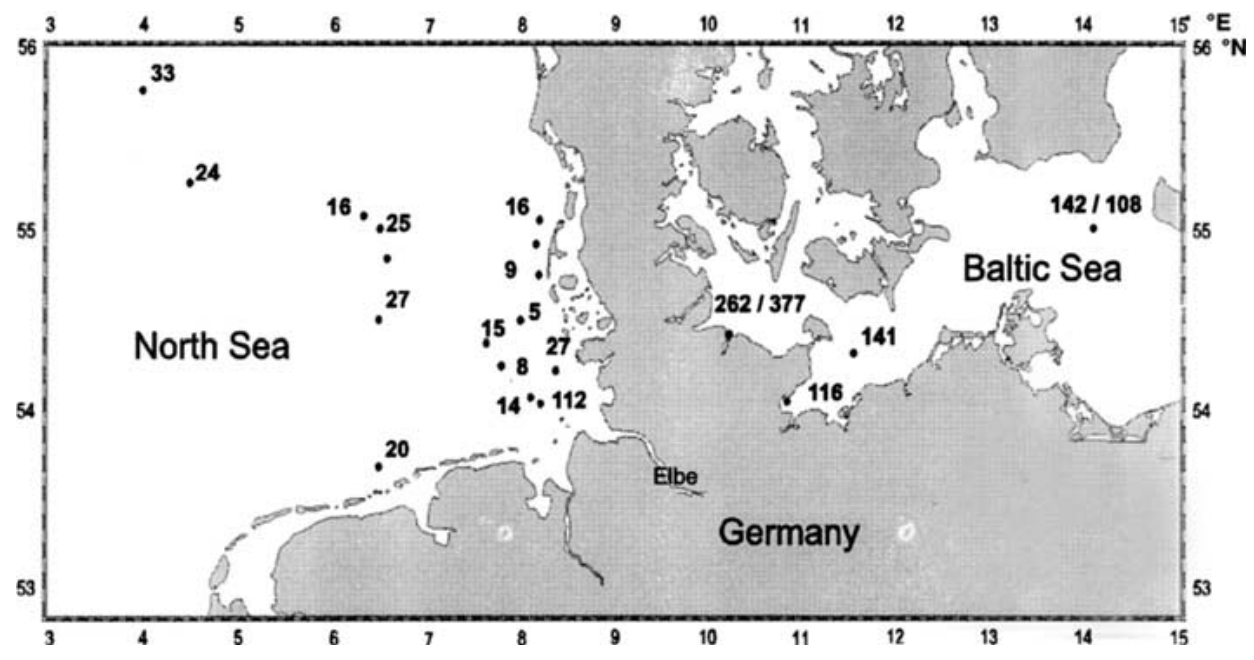

Fig. 1. Levels of SCCP+MCCP in sediments from the North and Baltic Seas. Results are in ng/g dry weight and were obtained by EI-MS/MS using the SCCP standard of $55.5 \%$.

Table 3. Comparison of SCCP and MCCP concentrations in sediment from North and Baltic Seas obtained with $\mathrm{CH}_{4} / \mathrm{CH}_{2} \mathrm{Cl}{ }_{2}-\mathrm{NICI}-\mathrm{MS}$ and given in $\mathrm{ng} / \mathrm{g}$ dry weight

\begin{tabular}{|c|c|c|c|c|}
\hline Sample & $\operatorname{SCCP}\left(\Sigma \mathrm{C}_{10}-\mathrm{C}_{13}\right)$ & $\operatorname{MCCP}\left(\Sigma \mathrm{C}_{14}-\mathrm{C}_{15}\right)$ & $\mathrm{SCCP}+\mathrm{MCCP}$ & $\mathrm{MCCP} / \mathrm{SCCP}$ \\
\hline \multicolumn{5}{|l|}{2001} \\
\hline 15 & 40 & 91 & 131 & 2.3 \\
\hline 16 & 21 & 48 & 69 & 2.3 \\
\hline 17 & 83 & 198 & 281 & 2.4 \\
\hline 19 & 105 & 131 & 236 & 1.3 \\
\hline \multicolumn{5}{|l|}{2002} \\
\hline 3 & 72 & 132 & 204 & 1.8 \\
\hline 18 & 128 & 303 & 431 & 2.4 \\
\hline 20 & 91 & 153 & 244 & 1.7 \\
\hline
\end{tabular}

Table 4. $\mathrm{CH}_{4} / \mathrm{CH}_{2} \mathrm{Cl}_{2}$-NICI-MS determination of the relative distribution of SCCP and MCCP components (\%) and in Baltic Sea sediments and selected technical mixtures. The average molar masses $(\mathrm{g} / \mathrm{mol})$ and the chlorine content $(\%)$ were also calculated

\begin{tabular}{|c|c|c|c|c|c|c|c|c|c|c|c|c|}
\hline & \multicolumn{2}{|c|}{ Molar mass } & \multicolumn{2}{|c|}{$\% \mathrm{Cl}$} & \multicolumn{6}{|c|}{ Main component } & \multicolumn{2}{|c|}{ Main component } \\
\hline & SCCP & $\mathrm{MCCP}$ & SCCP & $\mathrm{MCCP}$ & $\mathrm{C}_{10}$ & $\mathrm{C}_{11}$ & $\mathrm{C}_{12}$ & $\mathrm{C}_{13}$ & $\mathrm{C}_{14}$ & $\mathrm{C}_{15}$ & SCCP & MCCP \\
\hline 3 & 348 & 365 & 53 & 46 & 10 & 25 & 30 & 34 & 81 & 19 & $\mathrm{C}_{13} \mathrm{Cl}_{4}$ & $\mathrm{C}_{14} \mathrm{Cl}_{4}$ \\
\hline 15 & 361 & 387 & 53 & 48 & 8 & 11 & 39 & 42 & 59 & 41 & $\mathrm{C}_{13} \mathrm{Cl}_{4}$ & $\mathrm{C}_{14} \mathrm{Cl}_{5}$ \\
\hline 16 & 358 & 381 & 56 & 48 & 33 & 16 & 23 & 27 & 70 & 30 & $\mathrm{C}_{10} \mathrm{Cl}_{8}$ & $\mathrm{C}_{14} \mathrm{Cl}_{4}$ \\
\hline 17 & 379 & 394 & 55 & 49 & 6 & 10 & 45 & 40 & 65 & 35 & $\mathrm{C}_{12} \mathrm{Cl}_{6}$ & $\mathrm{C}_{14} \mathrm{Cl}_{5}$ \\
\hline 18 & 358 & 373 & 54 & 47 & 8 & 25 & 28 & 38 & 78 & 22 & $\mathrm{C}_{13} \mathrm{Cl}_{4}$ & $\mathrm{C}_{14} \mathrm{Cl}_{4}$ \\
\hline 19 & 391 & 391 & 56 & 49 & 6 & 7 & 9 & 78 & 62 & 38 & $\mathrm{C}_{13} \mathrm{Cl}_{7}$ & $\mathrm{C}_{14} \mathrm{Cl}_{6}$ \\
\hline 20 & 364 & 378 & 55 & 47 & 7 & 35 & 27 & 31 & 70 & 30 & $\mathrm{C}_{13} \mathrm{Cl}_{4}$ & $\mathrm{C}_{14} \mathrm{Cl}_{4}$ \\
\hline \multicolumn{13}{|c|}{ Quantification standard $^{\mathrm{a}}$} \\
\hline $\mathrm{SCCP}(55.5 \% \mathrm{Cl})$ & $354 \pm 0.8$ & & $55 \pm 0.4$ & & $9 \pm 0.3$ & $39 \pm 2.3$ & $33 \pm 2.2$ & $19 \pm 0.5$ & & & $\mathrm{C}_{11} \mathrm{Cl}_{5}$ & \\
\hline $\operatorname{MCCP}(57.0 \% \mathrm{Cl})$ & & $412 \pm 1.1$ & & $52 \pm 0.4$ & & & & & $80 \pm 4.2$ & $20 \pm 4.1$ & & $\mathrm{C}_{14} \mathrm{Cl}_{6}$ \\
\hline \multicolumn{13}{|l|}{ Technical mixtures } \\
\hline Hordaflex SP & & 415 & & 52 & & & & & 53 & 48 & & $\mathrm{C}_{14} \mathrm{Cl}_{6}$ \\
\hline Cloparin 50 & & 389 & & 49 & & & & & 69 & 31 & & $\mathrm{C}_{14} \mathrm{Cl}_{5}$ \\
\hline Hordalub 80 EM & & 389 & & 49 & & & & & 55 & 44 & & $\mathrm{C}_{14} \mathrm{Cl}_{5}$ \\
\hline Chlorparaffin $40 \mathrm{fl}$ & & 362 & & 45 & & & & & 67 & 33 & & $\mathrm{C}_{14} \mathrm{Cl}_{4}$ \\
\hline Chlorparaffin $45 \mathrm{fl}$ & & 373 & & 45 & & & & & 31 & 69 & & $\mathrm{C}_{15} \mathrm{Cl}_{5}$ \\
\hline Hordalub 17 & 332 & & 51 & & 7 & 34 & 34 & 25 & & & $\mathrm{C}_{12} \mathrm{C}_{5}$ & \\
\hline Hordalub 80 & 358 & & 55 & & 9 & 36 & 34 & 19 & & & $\mathrm{C}_{11} \mathrm{Cl}_{5}$ & \\
\hline Hordalub 500 & 387 & & 59 & & 9 & 47 & 30 & 11 & & & $\mathrm{C}_{11} \mathrm{Cl}_{6}$ & \\
\hline
\end{tabular}

\footnotetext{
${ }^{a}$ Five measurements at different days.
} 

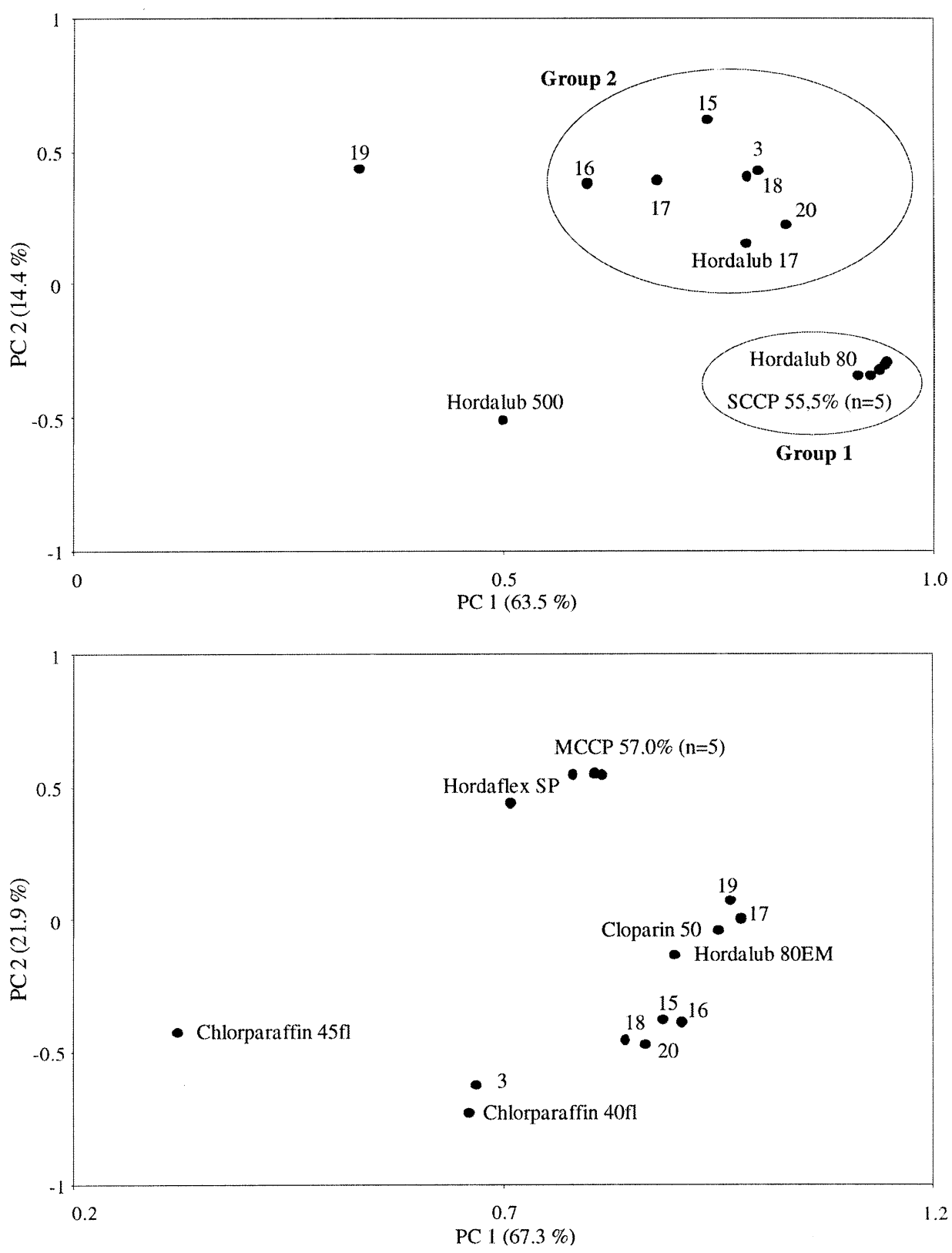

Fig. 2. Principal component analysis of the SCCP (A) and MCCP (B) congener and homologue patterns in sediments from the North and Baltic Seas and in technical mixtures from European producers. Results were obtained by $\mathrm{CH}_{4} / \mathrm{CH}_{2} \mathrm{Cl}_{2}$-NICI-MS. Two groups with related patterns are marked in the scoreplot for SCCPs. provided information about CP composition. Levels of SCCP and MCCP are presented in Table 3.

MCCP concentrations were highest in all seven samples (ratio MCCP/SCCP 1.3-2.4, Table 3). Similar observations were also made for German and Swiss river and lake sediments, (Bolliger et al. 2003; World Health Organization 1996). There, MCCP levels were 2 to 10 times higher. Reasons could be the higher consumption of MCCPs in Europe (World Health Organization 1996) or a preferred adsorption of MCCP. Uptake rates were in the range of $22-51 \times 10^{-2} \mathrm{~g} / \mathrm{g} / \mathrm{d}$ for $\mathrm{C}_{12} \mathrm{H}_{20} \mathrm{Cl}_{6}$ and $1.3 \times 10^{-2} \mathrm{~g} / \mathrm{g} / \mathrm{d}$ for $\mathrm{C}_{16} \mathrm{H}_{21} \mathrm{Cl}_{13}$ for sedimentsorbed ${ }^{14} \mathrm{C}$-polychlorinated alkanes by the oligochaete Lumbriculus variegates (Fisk et al. 1998). Bioaccumulation of sediment-sorbed CPs by oligoachetes was influenced by carbon chain length, chlorine content, and octanol-water partition coefficient. Both SCCPs and MCCPs $\left(\mathrm{C}_{14-18}, \sim 60 \% \mathrm{Cl}\right)$ were bioavailable, but the bioavailability decreased for MCCPs with higher chlorine content.

The calculated mean chlorine content was 53-56\% for SCCP and 46-49\% for MCCP in sediments. This was comparable to the SCCP reference standard used for quantification (calculated $55 \% \mathrm{Cl}$, average of five measurements, Table 4), but lower than for the applied MCCP standard (52\% $\mathrm{Cl}$, average of five measurements). Calculated molar masses in samples varied between 348 and $391 \mathrm{~g} / \mathrm{mol}$ for SCCP and 365 and $394 \mathrm{~g} / \mathrm{mol}$ for MCCP. The employed standards had $354 \mathrm{~g} / \mathrm{mol}(\mathrm{SCCP}, 55.5 \% \mathrm{Cl}$ ) and $412 \mathrm{~g} / \mathrm{mol}$ (MCCP, 57.0\% $\mathrm{Cl})$.

CPs with a chain length of $\mathrm{C}_{13}$ and $\mathrm{C}_{14}$ and between four and six chlorine atoms were dominating in sediments (for sample 16 the main SCCP compound was $\mathrm{C}_{10} \mathrm{Cl}_{8}$ ) compared to $\mathrm{C}_{11} \mathrm{H}_{19} \mathrm{Cl}_{5}$ and $\mathrm{C}_{14} \mathrm{H}_{24} \mathrm{C}_{16}$ in the reference standards. $50-87 \%$ 
of the SCCPs in sediments had chain lengths of $\mathrm{C}_{12}$ and $\mathrm{C}_{13}$, whereas $59-81 \%$ of the MCCPs had chain lengths of $\mathrm{C}_{14}$.

\section{Results of PCA}

The congener and homologue patterns for SCCPs and MCCPs observed in sediments were compared to those of technical mixtures from European producers. Results of the principal component analysis for SCCP are shown in the score plot in Figure 2A. The two principal components with the largest variance were selected. The variances of PC1 and PC2 for SCCPs were $63.5 \%$ and $14.4 \%$, respectively, in total $77.9 \%$. Hordalub 80 and the Ehrenstorfer SCCP mixture with $55.5 \%$ $\mathrm{Cl}$ formed Group 1. The mixtures had a similar congener and homologue pattern and chlorine content (55\%). Group 2 was formed by six sediment samples and Hordalub 17 . The calculated chlorine content of Hordalub 17 (51\%) was different from the sediment samples (53-56\%). Hordalub 17, samples 15,16 and 17 had a congener and homologue pattern with high relative abundances of $\mathrm{C}_{12}$ and $\mathrm{C}_{13}$ compounds ( $\mathrm{sum}>50 \%$ ), whereas samples 3,18 , and 20 showed higher relative abundances of $\mathrm{C}_{11}$ compounds (Table 4).

Hordalub 500 and sample 19 were separated from the rest. The technical mixture had a higher chlorine content (certified $62 \%$ ) and a different $\mathrm{CP}$ pattern with higher abundances of $\mathrm{C}_{11}(47 \%)$ congeners. The relative abundance of $\mathrm{C}_{13}$ compounds was $78 \%$ for sample 19 , whereas the chlorine content and average molar mass were comparable to the other sediments. Sediments sampled at the same site at two consecutive years (17 and 18, 19 and 20) showed a significantly different congener and homologue pattern. This might be caused by the differences in the TOC content and composition influencing the adsorbability of $\mathrm{CP}$. The congener patterns of the quantification standards (Table 4) were established at different days and also for newly prepared standard solutions. Relative deviations were $\leq 5 \%$ for SCCP and MCCP components.

Similarities with technical MCCP mixtures can be deduced from Table 4. The differences were only small between the sediments concerning MCCP congener and homologue patterns, molar masses, and chlorine contents. However, a comparison with technical mixtures showed the following: Hordaflex SP and MCCP mixture with $57.0 \%$ chlorine had the highest molar masses and chlorine contents. $\mathrm{C}_{14} \mathrm{H}_{24} \mathrm{Cl}_{16}$ was the main compound of both mixtures. Chlorparaffin $45 \mathrm{fl}$ was the only one with a higher relative abundance of $\mathrm{C}_{4}$ than $\mathrm{CH}$ compounds, The congener and homologue patterns, chlorine contents and molar masses of all sediment samples showed similar values as Cloparin 50, Hordalub 80 EM and Chlorparaffin 40fl (Figure 2B).

\section{Conclusion}

It seems from this study that the Baltic Sea is more highly contaminated by CPs than the North Sea. However, to confirm this, more data are necessary especially for the Baltic Sea. Concentrations of MCCP were higher than for SCCP. The concentration ratio of MCCP to SCCP in the sediments was comparable to those determined in river and lake sediments from Germany and Switzerland. The homologue and congener profiles in the studied samples were similar to technical mixtures produced in Europe.

Acknowledgments. This work was supported by the Environmental Agency in Berlin, Germany, under the project no, FKZ 20025 224/01 and by the Swiss National Science Foundation under the project no. 200020-101473.

\section{References}

BLMP (2002) Meeresumwelt 1997-1998. Bundesamt für Seeschifffahrt und Hydrographie (BSH), Hamburg

Bolliger R, Randegger-Vollrath A (2003) Kurzkettige chlorierte Paraffine-Stoffflussanalyse. Bundesamt für Umwelt, Wald und Landschaft (BUWAL), Bern, pp 96

Campbell I, McConnell G (1980) Chlorinated paraffins and the environment: 1. Environmental occurrence. Environ Sci Technol 14:1209-1214

Castells P, Santos FJ, Galceran MT (2004) Evaluation of three ionisation modes for the analysis of chlorinated paraffins by gas chromatography/ion-trap mass sppectrometry. Rapid Commun Mass Spectrom 18:529-536

European Chemicals Bureau (2002) Risk assessment of alkanes, $\mathrm{C}_{14-17}$, chloro. Draft. Available from http://ecb.jrc.it/existing-chemicals

European Commission (1999) Alkanes, $\mathrm{C}_{10-13}$, chloro (short chain length chlorinated paraffins). Joint Research Centre, Institute for Health and Consumer Protection, Ispra, pp 20

European Community (2000) Directive 2000/60/EC of the parliament and of the council of 23 October 2000 establishing a framework for community action in the field of water policy. Off $\mathrm{J}$ Eur Commun L327:1-72

European Community (2001) Decision No 2455/2001/EC of the parliament and of the council of 20 November 2001 establishing the list of priority substances in the field of water policy and amending Directive 2000/60/EC. Off J Eur Commun L331:1-5

Fisk AT, Wiens SC, Webster GRB, Bergmann W, Muir DCG (1998) Accumulation and depuration of sediment-sorbed $\mathrm{C}_{12^{-}}$and $\mathrm{C}_{16^{-}}$ polychlorinated alkanes by oligochaetes (Lumbriculus variegatus). Environ Toxicol Chem 17:2019-2026

GDCh Advisory Committee on Existing Chemicals of Environmental Relevance (1992) Chlorinated Paraffins. Hirzel, Stuttgart

Greenpeace (1995) Chlorparaffine-ein Umweltgift breitet sich aus. Greenpeace, Hamburg, pp 21

HELCOM (2002) Guidance document on short chained chlorinated paraffins (SCCP). EU, pp 21

Hüttig J, Oehme M (2005) Multivariate cluster analysis as a versatile tool for the quality assessment of short chain chloroparaffin quantification in environmental samples. J Environ Monit 7:319324

Kemmlein S, Hermeneit A, Rotard W (2002) Carbon skeleton analysis of chloroparaffins in sediment, mussels and crabs. Organohalogen Compds 59:279-282

Marvin CH, Painter S, Tomy GT, Stern GA, Braekevelt E, Muir DCG (2003) Spatial and temporal trends in short-chain chlorinated paraffins in lake Ontario sediments. Environ Sci Technol 37:4561-4568

Muir DCG, Stern GA, Tomy GT (2000) Chlorinated paraffins. In: Paasivirta P (ed) The handbook of environmental chemistry. Springer Verlag, Berlin, pp 203-236

Nicholls CR, Allchin CR, Law RJ (2001) Levels of short and medium chain length polychlorinated $n$-alkanes in environmental samples from selected industrial areas in England and Wales. Environ Pollut 114:415-430 
Parera J, Santos FJ, Galceran MT (2004) Microwave-assisted extraction versus Soxhlet extraction for the analysis of short-chain chlorinated alkanes in sediments. J Chromatogr A 1046:19-26

Reth M, Oehme M (2004) Limitations of low resolution mass spectrometry in the electron capture negative ionization mode for the analysis of short- and medium-chain chlorinated paraffins. Anal Bioanal Chem 378:1741-1747

Reth M, Zencak Z, Oehme M (2005) First study of congener group patterns and concentrations of short- and medium-chain chlorinated paraffins in fish from the North and Baltic Sea. Chemosphere 58:847-854

Stejnarova P, Coelhan M, Kostrhounova R, Parlar H, Holoubek I (2005) Analysis of short chain chlorinated paraffins in sediment samples from the Czech Republic by short-column GC/ECNIMS. Chemosphere 58:253-262

Stern GA, Tomy GT (2000) An overview of the environmental levels and distribution of polychlorinated paraffins. Organohalogen Compds 47:135-138

Stevens JL, Northcott Gl, Stern GA, Tomy GT, Jones KC (2003) PAHs, PCBs, PCNs, organochlorine pesticides, synthetic musks, and polychlorinated n-alkanes in U.K. sewage sludge: Survey results and implications. Environ Sci Technol 37:462-467

Tomy GT, Fisk AT, Westmore JB, Muir DCG (1998) Environmental chemistry and toxicology of polychlorinated $n$-alkanes. Rev Environ Contain Toxicol 158:53-128

Tomy GT, Muir DCG, Stern GA, Westmore JB (2000) Levels of $\mathrm{C}_{10^{-}}$ $\mathrm{C}_{13}$ polychloro- $n$-alkanes in marine mammals from the Arctic and the St. Lawrence River Estuary. Environ Sci Technol 34:16151619

Tomy GT, Stern GA, Lockhart WL, Muir DCG, J. Hüttig and M. Oehme (1999) Occurrence of $\mathrm{C}_{10}-\mathrm{C}_{13}$ polychlorinated $n$-alkanes in Canadian Midlatitude and Arctic lake sediments. Environ Sci Technol 33:2858-2863

Tomy GT, Stern GA, Muir DCG, Fisk AT, Cymbalisty CD, Westmore JB (1997) Quantifying $C_{10}-C_{13}$ polychloroalkanes in environmental samples by high-resolution gas chromatography electron capture negative ion high-resolution mass spectrometry. Anal Chem 69:2762-2771

World Health Organization (1996) Environmental health criteria 181-Chlorinated paraffins. WHO, Genf, pp 120

Zencak Z, Borgen A, Reth M, Oehme M (2005) Evaluation of four mass spectrometric methods for the analysis of polychlorinated $n$ alkanes. J Chromatogr A 1067:295-301

Zencak Z, Reth M, Oehme M (2003a) Dichloromethane as NICI reagent gas for the selective detection of polychlorinated $n$-alkanes. Organohalogen Compds 60:488-491

Zencak Z, Reth M, Oehme M (2003b) Dichloromethane-enhanced negative ion chemical ionization for the determination of polychlorinated $n$-alkanes. Anal Chem 75:2487-2492

Zencak Z, Reth M, Oehme M (2004) Determination of total polychlorinated $n$-alkane concentration in biota by electron ionizationMS/MS. Anal Chem 76:1957-1962

Zitko V (1973) Chromatography of chlorinated paraffins on alumina and silica columns. J Chromatogr 81:152-155 